\title{
PENGARUH PENDEKATAN SAINTIFIK PROSES MENGOMUNIKASIKAN DALAM MODEL TIME TOKEN TERHADAP HASIL BELAJAR BAHASA INDONESIA
}

\author{
I Putu Artawan \\ Jurusan Pendidikan Guru Sekolah Dasar, Universitas Pendidikan Ganesha \\ artawanputu.id.@gmail.com \\ Ni Wayan Arini \\ Jurusan Pendidikan Guru Sekolah Dasar, Universitas Pendidikan Ganesha \\ wayanarini@yahoo.co.id \\ Desak Putu Parmiti \\ Jurusan Pendidikan Guru Sekolah Dasar, Universitas Pendidikan Ganesha \\ dskpt_parmiti@yahoo.co.id
}

\begin{abstract}
Abstrak
Penelitian ini bertujuan untuk mengetahui pengaruh pendekatan saintifik proses mengomunikasikan dalam model time token terhadap hasil belajar bahasa Indonesia siswa kelas IV SD Gugus XIV Kecamatan Buleleng Kabupaten Buleleng tahun pelajaran 2017/2018. Jenis penelitian ini adalah kuasi eksperimen dengan rancangan non equivalent post-test only control group design. Populasi dalam penelitian ini adalah siswa kelas IV SD Gugus XIV Kecamatan Buleleng Kabupaten Buleleng tahun pelajaran 2017/2018. Sampel penelitian ditentukan dengan menggunakan teknik random sampling. Sekolah yang dijadikan sampel yaitu kelas IV SDN 1 Tukadmungga sebagai kelompok eksperimen dan siswa kelas IV SDN 1 Pemaron sebagai kelompok kontrol. Data hasil belajar bahasa Indonesia dikumpulkan dengan metode tes berupa tes objektif dan tes uraian. Teknik analisis yang digunakan adalah analisis deskritif dan uji-t. Berdasarkan analissi data dengan uji-t, diperoleh nilai $t_{\text {hitung }}=2,42$ lebih besar dari $t_{\text {tabel }}=2,006$ dengan taraf signifikasi 5\%. Hasil penelitian menunjukan terdapat pengaruh yang signifikan pendekatan saintifik proses mengomunikasikan dalam model time token terhadap hasil belajar bahasa Indonesia siswa. Di samping itu, didapatkan pula bahwa mean kelompok ekperimen adalah 29 dan mean kelompok kontrol adalah 26,29. Berdasarkan hal tersebut, penggunaan pendekatan saintifik proses mengomunikasikan dalam model time token berpengaruh positif terhadap hasil belajar bahasa Indonesia kelas IV SD Gugus XIV Kecamatan Buleleng Kabupaten Buleleng tahun pelajaran 2017/2018.
\end{abstract}

Kata Kunci: Pendekatan Saintifik, Time Token, Hasil Belajar

\begin{abstract}
This study is purpose to know the effect of scientific approach in which for communication process in time token model towards the learning result in Bahasa on students in IV grade of SD cluster XIVsub district, Buleleng regency in academic year 2017/2018. The study is quasi experiment with non-equivalent post-test only control group design. The population of this study were the students in IV grade of SD in cluster XIVsub district, Buleleng regency in academic year 2017/2018. The sample of this study was using random sampling technique. The school which was used as a sample was IV grade students in SDN 1 Tukadmungga as experiment group and the IV grade students in SDN 1 Pemaron as control group. The result of the learning Bahasa was collected using test instrument there were objective test and essay test. The descriptive analysis technique was used of this study uji-t, the result $t_{c o n t}=2,42$ high than $t_{\text {tabel }}=2,006$ the significance level was $5 \%$. The result of this study showed that there was significance effect of scientific approach communication process in time token model towards students result in learning Bahasa. Besides, the mean of experiment group was 29 and the mean of control group was 26,29. Based on that the using of scientific approach in communication process in time token model has positive effect towards the result of learning Bahasa in grade IV of SD in cluster XIV sub district, Buleleng regency in academic year 2017/2018.
\end{abstract}

Keywords: Scientific Approach, Time Token, Learning Result 


\section{Pendahuluan}

Pembelajaran bahasa Indonesia diberikan pada semua jenjang pendidikan di Indonesia salah satunya pada jenjang sekolah dasar. Pemberian pembelajaran bahasa Indonesia di sekolah dasar dilakukan untuk melatih kemampuan berbahasa siswa sejak dini. Dalam kontek pembelajaran di sekolah dasar, bahasa tidak saja digunakan para siswa untuk kepentingan pembelajaran saja melainkan juga untuk mempelajaari berbagai macam ilmu pengetahuan lain yang diajarkan di sekolah. Dibia dan Dewantara (2014:1) mengemukakan "Bahasa memegang peranan penting dalam mengembangkan potensi manusia dalam bidang kehidupan sebab bahasa tidak hanya sebagai alat komunikasi tetapi juga sarana untuk mengungkapkan berbagai macam gagasan". Dapat dikatakan belajar bahasa sebagai penentu keberhasilan dalam mengembangkan aspek kehidupan.

Pembelajaran bahasa Indonesia disekolah dasar diarahkan untuk meningkatkan kemampuan peserta didik untuk berkomunikasi dalam bahasa Inoneisia dengan baik dan benar, baik secara lisan maupun tertulis. Abidin $(2012 ; 5)$ menyatakan " pembelajaran bahasa Indonesia dapat diartikan sebagai serangkaian aktiivitas yang dilakukan siswa untuk mencapai keterampilan bahasa tertentu”. Keterampilan bahasa yang ingin dicapai disesuaikan dengan tahap perkembangan peserta didik.

Pembelajaran bahasa Indonesia sangat erat kaitanya dengan keterampilan berbahasa. Susanto $(2013 ; 242)$ menyatakan "pembelajaran bahasa terutama disekolah dasar tidak akan terlepas dari empat keterampilan berbahasa yaitu menyimak, berbicara, membaca, dan menulis". Keempat keterampilan berbahasa ini merupakan keterampilan yang wajib dimiliki peserta didik sebagai modal awal dalam berinteraksi dengan orang lain. Namun dalam penerananya keterampilan berbicara yang paling banyak digunakan dalam berkomunikasi saat pembelajaran. Hal ini dikarenakan interaksi dalam pembelajaran antara siswa dan guru terkait penyampaian materi belajar lebih banyak menggunakan keterampilan berbicara. Ningsih (2014:244) menyatakan "keterampilan berbicara diperlukan sebagai alat untuk menyatakan pendapat, gagasan, memberi informasi dan menerima informasi". Semakin baik keterampilan berbicara seseorang dalam berkomunikasi terkait gagasan, pendapat dan ide-idenya maka akan berpengaruh pula terhadap keterampilan-keterampilan berbahasa lainnya.

Keberhasilan pengajaran keterampilan berbicara di sekolah dasar dalam pembelajaran bahasa Indonesia tidak terlepas dari usaha seorang guru ataupun pendidik dalm meyalurkan informasi kepada siswa. Muslich (2012:63) menjelaskan "guru, metode, alat pengajaran, dan alat evaluasi merupakan sarana dalam pengajaran dalam rangkaian mencapai tujuan”. Oleh sebab itu komponen ini harus benar-benar menunjang pengajaran keterampilan berbicara. Pemilihan variasi pembelajaran yang memungkinkan anak dapat berinteraksi dan berkomunikasi dengan anak lainnya dalam mencari, menemukan, dan menggali sendiri pengetahuan melalui keterampilan berbicara sangatlah diperlukan. Berdasarkan pendapat di atas maka dibutuhkan pembelajaran bahasa di sekolah dasar yang dapat memfasilitasi siswa untuk mengembangkan keterampilan berbicara secara bertahap untuk menghasilkan siswa dengan kemampuan yang baik.

Salah satu yang memfasilitasi pengajaran keterampilan berbicara yaitu proses mengomunikasikan pada pendekatan saintifik. Kurniasih dan Sani (2014:56) menyatakan "mengomunikasikan adalah kegiatan belajar menyampaikan hasil pengamatan, kesimpulan berdasarkan hasil analisis secara lisan, tertulis, atau media lainnya”. Kegiatan ini dapata dilakukan melalui menceritakan apa yang ditemukan dalam kegiatan mencari informasi, mengasosiasikan dan menemukan pola. dengan penggunaan pendekatan saintifik terutama dalam proses mengomunikasikan pada pembelajaran bahasa Indonesia diharapkan siswa akan terlatih keterampilan berbicaranya terkait menyampaikan ide-ide, gagasan serta berkomunikasi dengan baik, jelas, singkat dan benar. Sehingga hasil belajaar bahasa Indonesia yang diperoleh siswa pun dapat meningkat.

Namun, pada kenyataanya proses pembelajaran bahasa Indonesia belum sesuai harapan. Hal ini diperkuat oleh hasil wawancara, observasi dan pencatatan dokumen di kelas IV SD gugus XIV Kecamatan Buleleng Kabupaten Buleleng. Dari hasil wawancara yang dilakukan dengan guru kelas IV SD di Gugus XIV Kecamatan Buleleng mengatakan kesulitan dalam membuat siswa aktif dalam mengomunikasikan pendapatnya. Selain itu, juga dinyatakan bahwa dalam pembelajaran jarang menggunakan model atau metode yang dapat menarik minat siswa dalam belajar.

Berdasarkan hasil observasi yang dilakukan terlehat banyak siswa yang tidak percaya diri dalam mengomunikasikan pendapatnya di depan kelas, bahkan terkesan malu-malu padahal ketika ditunjuk oleh guru, siswa tersebut bisa menjawab dengan baik. Selain itu juga siswa yang aktif mengomunikasikan pendapatnya di kelas hanya siswa yang berprestasi saja. Tentu hal ini membuat beberapa siswa menjadi tidak aktif dalam pembelajaran karena di dominasi oleh siswa yang percaya diri saja. Hal ini berdampak negatif pada hasil belajar bahasa Indonesia yang diperoleh siswa.

Temuan tentang rendahnya hasil belajar bahasa Indonesia siswa kelas IV SD di Gugus XIV Kecamatan Buleleng juga diperkuat oleh hasil UAS bahasa Indonesia. Berdasarkan pencatatan dukumen memperllihatkan bahwa rata-rata nilai UAS siswa kelas IV seperti disajikan dalam Tabel 1.

Tabel 1. Rata-Rata Nilai UAS Kelas IV SD Gugus XIV Kecamatan Buleleng 


\begin{tabular}{clcc}
\hline No & \multicolumn{1}{c}{ Nama Sekolah } & Rat-Rata Nilai UAS & KKM \\
\hline 1 & SDN 1 Pemaron & 69,96 & 70 \\
2 & SDN 2 Pemaron & 69,08 & 70 \\
3 & SDN1 Tukadmungga & 69,52 & 70 \\
4 & SDN 2 Tukadmungga & 70,06 & 70 \\
5 & SDN 3 Tukadmungga & 70,94 & 67 \\
\hline
\end{tabular}

Berdasarkan Tabel 1, tampak nilai rata-rata hasil UAS bahasa Indonesia siswa di Gugus XIV Kecamatan Buleleng relatif belum maksimal, dikarenakan dipengaruhi oleh beberapa faktor dalam pembelajaran. Dua faktor yang dapat memengaruhi tingkat hasil belajar siswa adalah cara cara siswa mengomunikasikan terkait apa yang dipelajarinya dan model pembelajaran yang diterapkan oleh guru.

Dari pemaparan tersebut, adapun upaya yang dapat dilakukan guna mengatasi kekurangan-kekurangan pembelajaran di lapangan oleh guru diantaranya yaitu menciptakan suatu pembelajaran yang efektif, menyenangkan, dan bermakna bagi siswa, sehingga semua siswa dapat ikut terlibat langsung tanpa ada yang bersikap pasif. Pembelajaran yang dapat dipilih dan sesuai untuk mengatasi permasalahan tersebut adalah pembelajaran yang difokuskan pada proses mengomunikasikan pendekatan saintifik dalam model time token.

Pendekatan saintifik yaitu proses pembelajaran yang dirancang sedemikian rupa agar peserta didik aktif secara aktif mengonstruk konsep, hukum atau prinsip melalui tahapan-tahapan mengamati (untuk mengidenfikasi atau merumuskan masalah), merumuskan masalah, mengajukan atau merumuskan hipotesis, mengumpulkan data dengan berbagai teknik, menganalisis data, menarik kesimpulan dan mengomunikasikan konsep, hukum atau prinsip yang di temukan (Daryanto,2014:51). Dalam penerapannya pendekatan saintifik mampu membuat siswa aktif melalau lima kegiatan belajar yang ada di dalamnya, lima kegiatan belajar tersebut meliputi mengamati, menanya, menalar, mencoba dan mengomunikasikan. Musfiqon dan Nurdyansyah (2015:38) menyatakan "pendekatan pembelajaran saintifik dimaksudkan untuk memberi pemahaman kepada peserta didik untuk mengetahui, memahami, mempraktikkan apa yang sedang dipelajari secara ilmiah". Oleh karena itu, dalam proses pembelajaran diajarkan agar peserta didik pencari tahu dari berbagai sumber melalui mengamati, menanya, mencoba, mengolah, menyajikan, menyimpulkan, dan mencipta untuk semua mata pelajaran.

Sedangkan Model time token merupakan salah satu varian dalam pembelajaran yang membantu siswa agar mendapatkan kesempatan menyampaikan pendapatnya didepan kelas melalui kartu bicara. Kurniasih dan Sani (2016:107) menyatakan bahwa model pembelajaran "time token merupakan salah satu contoh pembelajaran yang demokratis di sekolah". Model ini menjadikan aktivitas siswa menjadi titik perhatian utama dalam pembelajaran sehingga semua siswa mampu terlibat secara aktif.

Sedangkan Huda (2014:239) menjelaskan"model ini digunakan untuk melatih dan mengembangkan keterampilan sosial agar siswa tidak mendominasi pembicaraan atau diam sama sekali". Penggunaan model time token ini memiliki beberapa kelebihan dalam pembelajarannya. Ada pun kelebihan model time token adalah sebagai berikut: 1) Mendorong siswa untuk meningkatkan inisiatif dan partisipasinya dalam proses pembelajaran, 2) Siswa tidak mendominasi pembicara atau diam sama sekali, 3) Siswa menjadi aktif dalam kegiatan pembelajaran ketika gilirannya, 4) Meningkatkan kemampuan siswa dalam berkomunikasi, 5) Melatih siswa untuk mengungkapkan pendapatnya, 6) Menumbuhkan kebiasaan pada siswa untuk saling mendengarkan, berbagi, memberikan masukan dan keterbukaan terhadap kritik, 7) Mengajarkan siswa untuk menghargai pendapat orang lain, 8) Guru dapat berperan untuk mengajak siswa mencari solusi bersama terhadap masalah yang di temui, dan 9) Tidak memerlukan banyak media.

Model time token merupakan salah satu varian dalam pembelajaran yang membantu siswa agar mendapatkan kesempatan menyampaikan pendapatnya didepan kelas melalui kartu bicara. Sintak model time token ini akan dipadukan dengan tahapan pendekatan saintifik yang berfokus pada tahapan mengomunikasikan, sehingga pembelajaran yang dilakukan menjadi lebih bermakna.

Berdasarkan uraian di atas, maka dikaji lebih luas permasalah tersebut dalam sebuah penelitian dengan judul "Pengaruh Pendekatan Saintifik Proses Mengomunikasikan dalam model Time Token Terhadap Hasil Belajar Bahasa Indonesia Kelasa IV SD Gugus XIV Kecamatan Buleleng Kabupaten Buleleng Tahun Pelajaran 2017/2018". Tujuan dari penelitian ini adalaah untuk mengetahui pengaruh pendekatan saintifik proses mengomunikasikan dalam model time token terhadap hasil belajar bahasa Indonesia siswa kelas IV SD Gugus XIV Kecamatan Buleleng Kabupaten Buleleng tahun pelajaran 2017/2018.

\section{Metode}

Penelitian ini dilaksanakan di SD Gugus XIV Kecamatan Buleleng Kabupaten Buleleng dengan rentang waktu 2 April - 30 April 2018. Jenis penelitian ini adalah penelitian semu dengan rancangan penelitian yang digunakan adalah non-equivalen post-test only control group design. Desain ini dapat dilihat pada Tabel 2. 
Tabel 2. Desain Penelitian

\begin{tabular}{lccc}
\hline & Kelompok & Perlakuan & Post-test \\
\hline Eksperimen & & $\mathrm{X} 1$ & $\mathrm{O} 1$ \\
Kontrol & - & $\mathrm{O} 2$ \\
\hline
\end{tabular}

Keterangan:

$\begin{array}{ll}\mathrm{X} 1 & \text { : perlakuan kelompok eksperimen } \\ - & \text { : perlakuan kelompok kontrol } \\ \mathrm{O} 1 & \text { : post-test kelompok eksperimen } \\ \mathrm{O} 2 & \text { : post-test kelompok kontro }\end{array}$

Tabel 3. Distribusi Populasi Penelitian

\begin{tabular}{|c|c|c|}
\hline No & Nama Sekolah & Jumlah Siswa \\
\hline 1 & SDN 1 Pemaron & 28 \\
\hline 2 & SDN 2 Pemaron & 24 \\
\hline 3 & SDN 1 Tukadmungga & 27 \\
\hline 4 & SDN 2 Tukadmungga & 17 \\
\hline 5 & SDN 3 Tukadmungga & 18 \\
\hline
\end{tabular}

Pengambilan sampel dilakukan menggunakan teknik random sampling. Sampel dari penelitian ini adalah SDN 1 Tukadmunggga sebagai kelompok eksperimen dan SDN 1 Pemaron sebagai kelas kontrol.

Penelitian ini melibatkan dua variabel penelitian yaitu variabel bebas dan variabel terikat. Variabel bebas dalam penelitian ini adalah pendekatan saintifik proses mengomunikasikan dalam model time token dan variabel terikatnya adalah hasil belajar bahasa Indonesia.

Data hasil belajar bahasa Indonesia siswa dikumpulkan melalui metode tes. Bentuk tes hasil belajar yang digunakan dalam penelitian ini yaitu tes objektif bentuk pilihan ganda dan tes uraian. Tes objektif yang digunakan berjumlah 25 butir soal dan tes uraian yang digunakan berjumlah 5 butir soal. Sebelum tes digunakan, terlebih dahulu instrumen diujicobakan untuk mengetahui validitas, reliabelitas, tingkat kesukaran, dan daya beda soal.

Data yang diperoleh kemudian dianalisis secara deskriptif dengan mencari mean, median, modus, standar devariasi,dan varians skor. Teknik analisis data yang digunakan untuk menguji hipotesis dalam penelitian ini menggunakan uji-t. Namun sebelum melakukan uji-t terlebih dahulu dilakukan uji praysarat yang terdiri dari uji normalitas dan uji homogenitas. Dalam penelitian ini uji-t menggunakan rumus polled varians.

Pengambilan sampel dilakukan menggunakan teknik random sampling. Sampel dari penelitian ini adalah SDN 1 Tukadmunggga sebagai kelompok eksperimen dan SDN 1 Pemaron sebagai kelas kontrol.

Penelitian ini melibatkan dua variabel penelitian yaitu variabel bebas dan variabel terikat. Variabel bebas dalam penelitian ini adalah pendekatan saintifik proses mengomunikasikan dalam model time token dan variabel terikatnya adalah hasil belajar bahasa Indonesia.

Data hasil belajar bahasa Indonesia siswa dikumpulkan melalui metode tes. Bentuk tes hasil belajar yang digunakan dalam penelitian ini yaitu tes objektif bentuk pilihan ganda dan tes uraian. Tes objektif yang digunakan berjumlah 25 butir soal dan tes uraian yang digunakan berjumlah 5 butir soal. Sebelum tes digunakan, terlebih dahulu instrumen diujicobakan untuk mengetahui validitas, reliabelitas, tingkat kesukaran, dan daya beda soal.

Data yang diperoleh kemudian dianalisis secara deskriptif dengan mencari mean, median, modus, standar devariasi,dan varians skor. Teknik analisis data yang digunakan untuk menguji hipotesis dalam penelitian ini menggunakan uji-t. Namun sebelum melakukan uji-t terlebih dahulu dilakukan uji praysarat yang terdiri dari uji normalitas dan uji homogenitas. Dalam penelitian ini uji-t menggunakan rumus polled varians.

\section{Hasil dan Pembahasan}

Deskripsi data hasil penelitian meliputi (1) deskripsi data hasil post-test dan (2) deskripsi data hasil post-test kelompok kontrol. Hasil analisis deskripsi data hasil belajar bahasa Indonesia antara kelompok eksperimen dan kelompok kontrol disajikan pada Tabel 4.

Tabel 4. Hasil Analisis Deskritif Data Hasil Belajar Bahasa Indonesia

\begin{tabular}{lccc}
\hline Statistik & $\begin{array}{c}\text { Kelompok } \\
\text { Eksperimen }\end{array}$ & Kelompok Kontrol \\
\hline Mean & 29 & 26,29
\end{tabular}




$\begin{array}{lcc}\text { Median } & 29,34 & 25,81 \\ \text { Modus } & 29,85 & 25,16 \\ \text { Varians } & 17,14 & 18,92 \\ \text { Standar Deviasi } & 4,14 & 4,35 \\ \text { Skor Maksimal } & 37 & 35 \\ \text { Skor Minimal } & 20 & 18\end{array}$

Dari Tabel 4, hasil deskripsi data kemudian diketahui kelompok eksperimen memiliki mean= 29, median 29,34 dan modus 29,85 yang berarti mean lebih kecil dari median dan median lebih kecil dari modus (M $<\mathrm{Md}<$ Mo), maka data termasuk pada distribusi juling negatif. yaitu sebagian besar skor hasil belajar bahasa Indonesia cenderung tinggi. Adapun kurva disajikan pada Gambar 1 berikut.

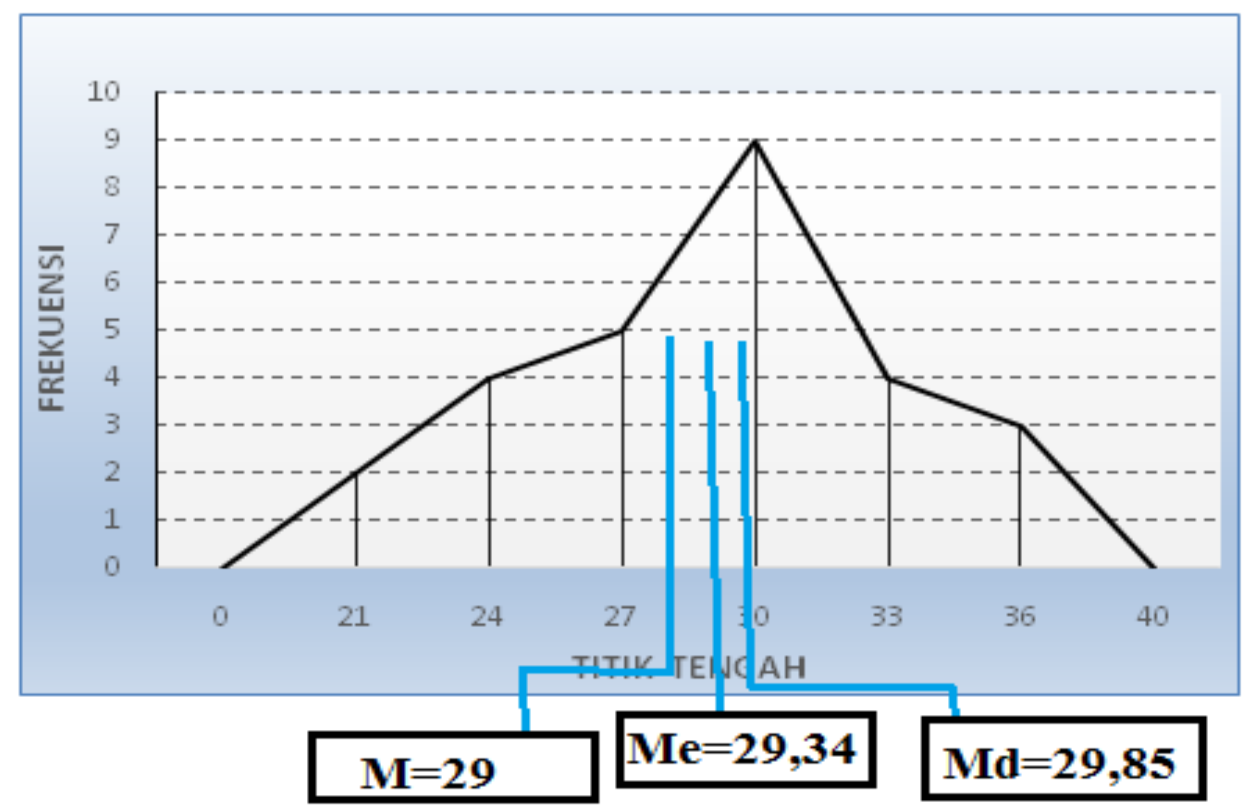

Gambar 1. Grafik poligon data hasil belajar kelompok eksperimen

Sedangkan kelompok kontrol memiliki mean $=26,29$, median $=25,81$, dan modus $=25,61$ yang berarti mean lebih besar dari median dan median lebih besar dari modus ( $\mathrm{M}>\mathrm{Md}>\mathrm{Mo}$ ), maka data berada pada distribusi data juling positif yaitu skor hasil belajar bahasa Indonesia cenderung rendah. Adapun kurva disajikan pada Gambar 2 berikut: 


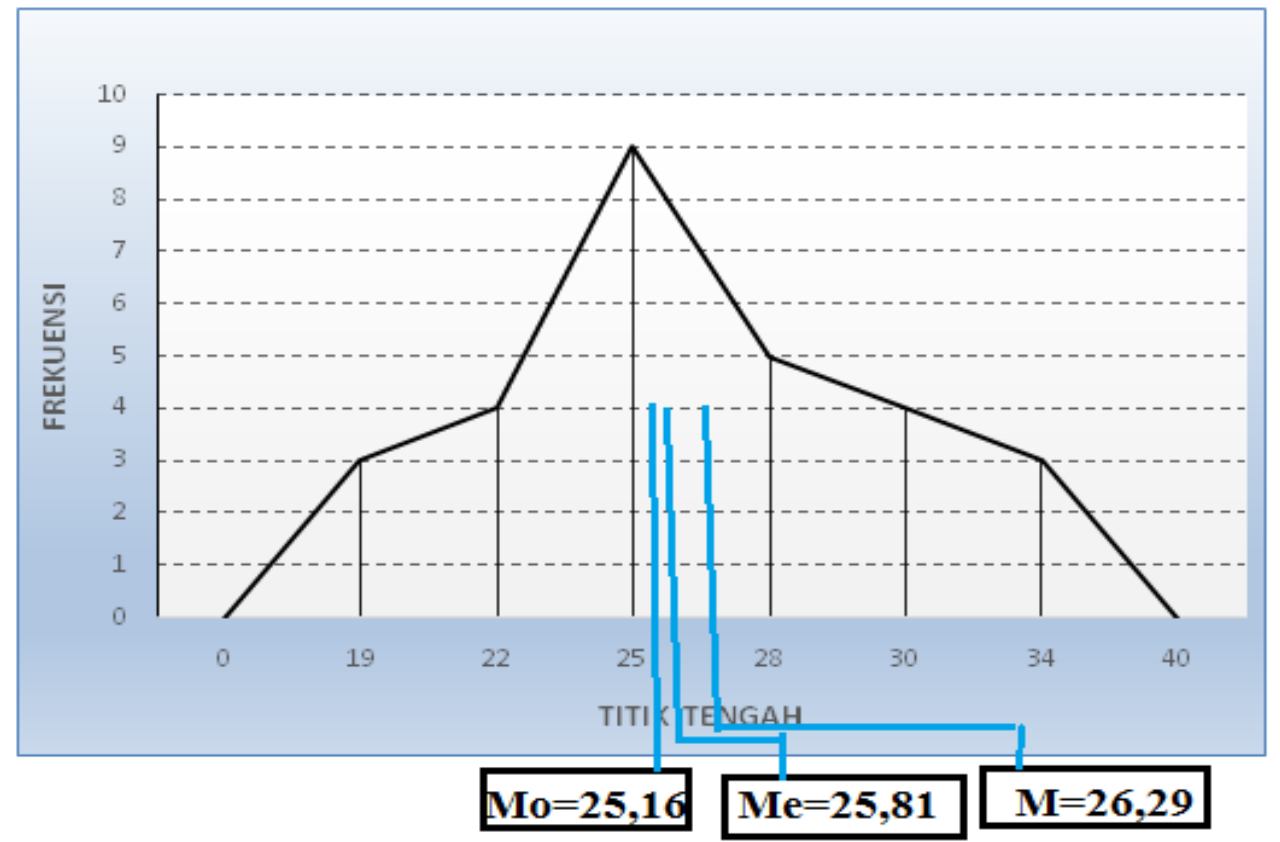

Gambar 2. Grafik poligon data hasil belajar kelompok kontrol

Sebelum melakukan uji hipotesis terlebih dahulu dilakukan uji prasyarat analisis. Uji prasyarat analisis data dilakukan dengan uji normalitas dan uji homogenitas varians. Uji normalitas dimaksudkan untuk menyakinkan bahwa sampel benar-benar bersal dari populasi yang berdistribusi normal pada dua kelompok data. Pada penelitian ini uji normalitas dilakukan dengan menggunakan rumus Chi-kuadrat. Ringkasan uji normalitas kelompok eksperimen dan kontrol dapat dilihat pada Tabel 5.

Tabel 5. Ringkasan Hasil Uji Normalitas

\begin{tabular}{clccc}
\hline No & Sampel Penelitian & $\mathbf{X}^{\mathbf{2}}{ }_{\text {hitung }}$ & Nilai Kritsi dengan Taraf Signifikasi 5\% & Status \\
\hline 1 & Kelompok Eksperimen & 0,753 & 7,815 & Normal \\
2 & Kelompok Kontrol & 1,775 & 7,815 & Normal \\
\hline
\end{tabular}

Kreteria pengujian normalitas adalah jika $\mathrm{X}_{\text {hit }}^{2}<\mathrm{X}_{\text {tab }}^{2}$, maka data berdistribusi normal. Berdasarkan

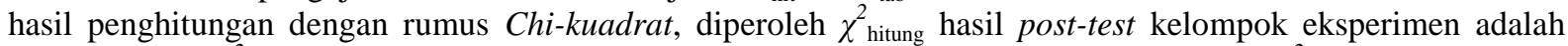
0,753 dan dan $\chi_{\text {tabel }}^{2}$ dengan taraf signifikasi $5 \%$ dan $\mathrm{dk}=3$ adalah 7,815. Hal ini berarti, $\chi_{\text {hitung hasil post-test }}^{2}$ kelompok eksperimen lebih kecel dari $\chi_{\text {tabel }}^{2}\left(\chi_{\text {hitung }}^{2}>\chi_{\text {tabel }}^{2}\right)$ sehingga data berdistribusi normal. Sedangkan $\chi_{\text {hitung }}^{2}$ hasil post-test kelompok kontrol adalah 1,775 . Hal ini berarti $\chi_{\text {hitung }}^{2}$ hasil post-test kelompok eksperimen lebih kecil dari $\chi_{\text {tabel }}^{2}\left(\chi_{\text {hitung }}^{2}>\chi_{\text {tabel }}^{2}\right)$ sehingga data berdistribusi normal.

Sedangkan, untuk mengitung uji homogenitas dilakukan degan menggunakan rumus uji-F. Uji ini dilakukan terhadap varians pasanagan antara kelompok eksperimen dan kelompok kontrol. Kreteria data homogen yaitu jika $\mathrm{F}_{\text {hitung }}<\mathrm{F}_{\text {tabel }}$, maka data tersebut homogen. Rangkuman hasil uji homogenitas varians antara kelompok eksperimen dan kelompok kontrol disajikan pada Tabel 6.

Tabel 6. Rangkuman Hasil Uji Homogenitas Varians

\begin{tabular}{clccc}
\hline No & Sampel Penelitian & $\mathbf{X}_{\text {hitung }}^{\mathbf{2}}$ & $\begin{array}{c}\text { Nilai Kritsi } \\
\text { dengan Taraf } \\
\text { Signifikasi 5\% }\end{array}$ & Status \\
\hline 1 & Kelompok Eksperimen & 0,753 & 7,815 & Normal \\
2 & Kelompok Kontrol & 1,775 & 7,815 & Normal \\
\hline
\end{tabular}

Berdasarkan hasil penghitungan, dapat diketahui bahwa $\mathrm{F}_{\text {hitung }}$ hasil post-test kelompok eksperimen dan kelompok kontrol adalah 1,10 sedangkan harga $F_{\text {tabel }}$ dengan $d b_{\text {pembilang }}=26$ dan $d_{\text {penyebut }}=27$ pada taraf 
signifikasi 5\% adalah 1,88. Hal ini berarti, variasi hasil post-test kelompok eksperimen dan kelompok kontrol adalah homogen.

Berdasarkan uji prasyarat data, diperoleh bahwa data hasil belajar post-test kelompok eksperimen dan kelompok kontrol normal dan homogen. Setelah diperoleh hasil uji prasyarat analisis data kemudian dilanjutkan dengan pengujian hipotesis penelitian $\left(\mathrm{H}_{1}\right)$ dan hipotesis nol $\left(\mathrm{H}_{0}\right)$. Pengujian hepotesis dilakukan dengan menggunakan uji-t dengan rumus polled varians dengan kriteria jika $t_{\text {hitung }}>t_{\text {tabel }}$ maka $H_{0}$ ditolak dan $H_{1}$ diterima. Hasil uji-t disajikan dalam Tabel 7.

Tabel 7. Rangkuman Hasil Uji-t

\begin{tabular}{clcccccc}
\hline No & Kelompok & $\mathbf{N}$ & $\mathbf{X}$ & $\mathbf{S 2}$ & $\mathbf{t}_{\text {hitung }}$ & $\mathbf{t}_{\text {tabel }}$ & Keterangan \\
\hline 1 & Eksperimen & 27 & 29 & 17,14 & 2,42 & 2,006 & Ho ditolak \\
2 & Kontrol & 28 & 26,29 & 18,92 & & & \\
\hline
\end{tabular}

Berdasarkan hasil penghitungan uji-t, diperoleh $\mathrm{t}_{\text {hitung }}$ sebesar 2,42 , sedangkan $\mathrm{t}_{\text {tabel }}$ denga $\mathrm{db}=53$ pada signifikasi $5 \%$ adalah 2,006. Hal ini berarti $t_{\text {hitung }}$ lebih besar dari $t_{\text {tabel }}\left(t_{\text {hitung }}>t_{\text {tabel }}\right)$, sehingga $\mathrm{H}_{0}$ ditolak dan $\mathrm{H}_{1}$ diterima. Dengan demikian, maka dapat diinterprestasikan bahwa terdapat pengaruh yang signifikan pendekatan saintifik proses mengomunikasikan dalam model time token hasil belajar bahasa Indonesia yang dibelajarkan menggunakan pada siswa kelas IV SD Gugus XIV Kecamatan Buleleng Kabupaten Buleleng tahun pelajaran $2017 / 2018$.

Penggunaan pendekatan saintifik proses mengomunikasikan dalam model time token berpengaruh positif terhadap hasil belajar bahasa Indonesia yang diperoleh siswa kelompok eksperimen. Hasil belajar bahasa Indonesia siswa yang tergolong tinggi pada kelompok eksperimen dipengaruhi oleh beberapa faktor.

Pertama, penggunaan pendekatan saintifik membuat siswa memiliki sikap aktif dan bersemangat pada saat mengikuti pembelajaran. Siswa menjadi aktif dalam pembelajaran terlihat dari antusias mereka dalam mencari jawaban dan menyampaikan pendapatnnya di dalam kelas. Selain itu, siswa pun berlomba-lomba dalam menyampaikan pendapat pada saat pembelajaran. Munculnya sikap aktif pada diri siswa akan melatihnya dalam menencari informasi-informasi baru dan mengontruksinya menjadi pengetahuannya. Pada akhirnya siswa akan terbiasa aktif untuk mengontruksi berbagai pengetahuanya sendiri walaupun tanpa adanya bimbingan dari guru. Hal ini sejalan dengan pendapat Daryanto (2014:51) menyatakan "pendekatan saintifk dirancang sedemikian rupa agar peserta didik aktif dalam mengontruksi pengetahuan yang ditemukannya". Hasil temuan ini didukung penelitian Mustikawati (2015) yang menunjukan bahwa siswa menjadi lebih aktif dengan penggunaan pendekatan saintifik dalam pembelajaran.

Kedua, kegiatan pembelajaran yang dilakukan oleh siswa lebih demokratis. Hal ini dikarenakan dengan penggunaan time token dapat membuat pembelajaran tidak didominasi oleh beberapa siswa. Setiap siswa diberikan kesempatan yang sama dalam mengomunikasikan pendapatnya di depan kelas, sehingga tidak ada siswa yang diam sama sekali dalam pembelajaran. Pembelajaran yang dilaksanakan pun menjadi lebih aktif dikarenakan setiap siswa diwajibkan berpartisipasi dalam mengajukan pendapatnya. Keterlibatan siswa dalam berpendapat akan memunculkan keterapilan sosial dalam diri siswa. Keterampilan sosial ini tidak hanya berguna di dalam pembelajaran tetapi juga berguna di lingkungan keluarga dan masyarakat. Hal ini sesuai dengan pendapat Aqib (2013:33) menyatakan "time token digunakan untuk mengajarkan keterampilan sosial, selain itu juga untuk menghindari siswa mendominasi pembicaraan atau siswa diam sama sekali”. Dengan demikian, semua siswa pun menjadi aktif dan proses pembelajaran menjadi menyenangkan dan bermakna. Hasil ini sesuai dengan penelitian Juliati (2013) yang menunjukkan bahwa penggunaan time token mampu membuat siswa aktif dalam mengomunikasikan pendapatnya (berbicara) di dalam kelas.

Berdasarkan pemaparan dan temuan secara emperik, teori, maupun penelitian yang sejalan menunjukan bahwa pembelajaran dengan menggunakan pendekatan saintifik proses mengomunikasikan dalam model time token berpengaruh positif terhadap hasil belajar bahasa Indonesia siswa.

\section{Simpulan}

Berdasarkan hasil pengujian hepotesis dan pembahasan, maka dapat disimpulkan bahwa terdapat pengaruh yang signifikan pendekatan saintifik proses mengomunikasikan dalam model time token terhadap hasil belajar bahasa Indonesia siswa kelas IV SD Gugus XIV Kecamatan Buleleng Kabupaten Buleleng Tahun pelajaran 2017/2018. Hal ini membuktikan bahwa penggunaan pendekatan saintifik proses mengomunikasikan dalam model time token memiliki pengaruh yang positif terhadap hasil belajar bahasa Indonesia siswa kelas IV SD Gugus XIV Kecamatan Buleleng Kabupaten Buleleng tahun pelajaran 2017/2018.

Berdasarkan temuan-temuan dalam penelitian ini dapat disampaikan saran-saran kepada beberapa pihak yaitu kepada guru hendaknya mampu memberi motivasi dalam mengembangkan lebih lanjut kompetensinya 
dalam mengelola pembelajaran untuk mewujudkan pembelajaran yang menyenangkan, novatif, efektif, dan meningkatkan hasil belajar siswa. Kepala sekolah agar menjadikan pendekatan saintifik proses mengomunikasikan dalam model time token menjadi salah satu variasi pembelajaran yang diterapkan oleh guru. Peneliti lain yang berminat mengadakan penelitian lanjut tentang tentang pendekatan saintifik proses mengomunikasikan dalam model time token agar memperhatikan kendala-kendala yang dialami dalam penelitian ini sebagai pertimbangan dan penyempurnaan penelitian yang akan dilaksanakan.

\section{Daftar Pustaka}

Abidin, Yunus. 2012. Pembelajaran Bahasa Berbasi Pendidikan Karakter. Bandung: PT Refika Aditama Aqib, Zainal. 2013. Model-Model, Media, dan Strategi Pembelajaran Kontekstual (Inovatif). Bandung:Yrama Widya

Daryanto. 2014. Pendekatan Pembelajaran Saintifik Kurikulum 2013. Yogjakarta: Gava Media

Dibia, I Ketut dan I Putu Mas Dewantara. 2014.Bahasa Indonesia Keilmuan. Singaraja: Universitas Pendidikan Ganesha

Huda, Miftahul. 2014. Model-Model Pengajaran dan Pembelajaran.Yogjakarta: Pusta pelajar

Juliati,Wayan. 2013. "Pengaruh model Time Token berbantuan gambar berseri terhadap keterampilan birbicara siswa kelas V SD gugus I Gianyar”. E-jurnal Mimbar PGSD. Universitas Pendidikan Ganesha, Vol:1, No: 2,9

Kurniasih, Imas dan Berlin Sani. 2014. Ragam Pengembangan Model Pelajaran. Jakarta: Kata Pena

Musfiqon, Hm dan Nurdyansyah. 2015. Pendekatan Pembelajaran Saintifik. Sidoarjo: Nizamia Learning Center.

Muslich, Mansnur.2012. Bahasa Indonesia Pada Era Globalisasi.Jakarta: Bumi Aksara.

Mustikawati, Nyoman Diah. 2015. "Pengaruh Pendekatan Saintifik Terhadap Hasil Belajar Keterampilan Menyimak dalam Mata Pelajaran Bahasa Indonesia Tema Cita-Citaku pada Siswa Kelas IV SDN Desa Peguyangan Ditinjau Dari Jenis Pertanyaan Guru". E-jurnal Mimbar PGSD.Universitas Pendidikan Ganesha Vol.3 No1

Ningsih, Suwarti. 2014.’Peningkatan Keterampilan Berbicara Melalui Metode Bercerita Siswa Kelas III SD Negeri 1 Beringin Jaya Kecamatan Bumi Raya Kabupaten Morowali”. Jurnal Kreatif Tadulako Online. Vol:2, No: 4, 244

Susanto, Ahmad. 2013. Teori Belajar dan Pembelajaran di Sekolah Dasar. Jakarta: Kencana 